\title{
PROBLEMATIKA ASSET RECOVERY DALAM PENGEMBALIAN KERUGIAN NEGARA AKIBAT TINDAK PIDANA KORUPSI
}

\author{
Kajian Putusan Nomor 62/Pid.Sus/Tipikor/2013/PN.PBR \\ PROBLEMATICS OF ASSET RECOVERY IN
RESTORING STATE LOSS DUE TO CORRUPTION
}

An Analysis of Court Decision Number 62/Pid.Sus/Tipikor/2013/PN.PBR

\author{
Ade Mahmud \\ Fakultas Hukum Universitas Islam Bandung \\ J1 Ranggagading No. 8, Bandung 40116 \\ E-mail: ademahmud100@yahoo.com
}

Naskah diterima: 12 Oktober 2017; revisi: 13 November 2018; disetujui: 6 Desember 2018

http://dx.doi.org/10.29123/jy.v11i3.262

\begin{abstract}
ABSTRAK
Majelis hakim dalam Putusan Nomor 62/Pid.Sus/ Tipikor/2013/PN.PBR telah menjatuhkan pidana penjara dan denda bagi terpidana korupsi. Putusan ini dilihat dari sisi kerugian ekonomi menyisakan problem tersendiri karena tidak memulihkan kerugian materiil yang dialami Kabupaten Indragiri Hulu dan berdampak pada keterlambatan pelayanan bagi masyarakat. Realitas ini tidak sejalan dengan teori pengembalian aset (asset recovery) yang setia pada prinsip "berikan kepada negara apa yang menjadi haknya." Rumusan masalah dalam penelitian ini adalah apakah Putusan Nomor 62/Pid.Sus/ Tipikor/2013/PN.PBR sudah mampu mengembalikan kerugian keuangan negara dan bagaimana problematika asset recovery akibat tindak pidana korupsi. Metode penelitian menggunakan penelitian hukum normatif (yuridis normatif). Hasil penelitian menunjukkan Putusan Nomor 62/Pid.Sus/Tipikor/2013/PN.PBR belum mengembalikan kerugian negara karena tidak memberikan pemulihan (restorasi) terhadap kerugian materiil yang diderita Kabupaten Indragiri Hulu yang ditimbulkan akibat pertentangan antara pertimbangan hukum dengan putusan akhirnya. Problematika
\end{abstract}

pemulihan aset (asset recovery) dihadapkan pada realitas ketidakmampuan terpidana korupsi untuk membayar pidana uang pengganti karena secara normatif dimungkinkan dalam Pasal 18 ayat (3) Undang-Undang Nomor 31 Tahun 1999 tentang Pemberantasan Tindak Pidana Korupsi. Padahal kenyataaannya masih ada aset tersembunyi milik terpidana yang belum dilakukan penyitaan oleh penegak hukum. Akibatnya asset recovery tidak bisa dicapai karena terpidana memilih menjalani pidana subsider dan negara tetap merugi.

Kata kunci: korupsi, pemulihan aset, kerugian negara.

\section{ABSTRACT}

In Court Decision Number 62/Pid.Sus/Tipikor/2013/ PN.PBR, the panel of judges had dropped imprisonment and fines for the offenders in cases of corruption. In terms of economic losses, this decision leaves its own problem because it does not recover material losses suffered by Indragiri Hulu Regency and the impact on service delay for the community. This reality is not in line with the theory of asset recovery adhering to the principle of "give to state what she deserves." The 
formulation of the problem in this study is whether the Court Decision Number 62/Pid.Sus/Tipikor/2013/ PN.PBR has been able to restore state financial loss, and how the problem of asset recovery is caused by criminal acts of corruption. The research method used is a normative legal research. The results of the study show that Court Decision Number 62/Pid.Sus/ Tipikor/2013/PN.PBR has not yet restored the state loss as for not providing recovery of assets losses suffered by
Indragiri Hulu Regency due to conflicts between legal considerations and the final decision. The fact is there are still hidden assets belonging to the convict, that have not been confiscated by law enforcement. As a result, asset recovery cannot be achieved because the convicts choose to undergo subsidies, and the state still loses.

Keywords: corruption, assets recovery, state loss.

\section{PENDAHULUAN}

\section{A. Latar Belakang}

Seorang hakim dalam memutus perkara harus ekstra hati-hati, hakim perlu memperhatikan faktor keseimbangan untuk melindungi kepentingan pelaku, korban, dan masyarakat secara keseluruhan sehingga hakim dituntut harus arif dan bijaksana (Fuady, 2010: 176). Untuk menentukan kesalahan seorang pelaku hakim harus mendasarkan pada dua alat bukti yang sah didukung dengan keyakinan (nurani) hakim bahwa terdakwa bersalah (Alfitra, 2012: 29).

Putusan hakim akan terasa begitu dihargai dan mempunyai nilai kewibawaan, jika putusan tersebut merefleksikan rasa keadilan hukum masyarakat dan merupakan sarana bagi masyarakat pencari keadilan untuk mendapatkan kebenaran dan keadilan. Sebelum seorang hakim memutus suatu perkara, maka ia akan menanyakan terlebih dahulu kepada hati nuraninya sendiri, apakah putusan ini nantinya akan adil dan bermanfaat (kemaslahatan) bagi manusia atau sebaliknya akan lebih banyak menimbulkan kerusakan (kemudaratan), sehingga untuk itulah seorang hakim diharapkan mempunyai otak yang cerdas, dan memiliki hati nurani yang bersih (Rifa'i, 2014: 3).
Itulah sebabnya hakim dituntut untuk menghasilkan putusan yang berkualitas. Putusan hakim yang berkualitas dalam konteks ini adalah putusan perkara pidana yang didasarkan pada pertimbangan hukum sesuai fakta yang terungkap di persidangan, sesuai undang-undang dan keyakinan hakim tanpa terpengaruh berbagai intervensi internal dan eksternal sehingga dapat dipertanggungjawabkan secara profesional kepada publik (the truth hand justice) (Sutatiek, 2013: 29).

Praktiknya sering kali ditemukan putusan hakim yang bertentangan dengan fakta-fakta yang terungkap di persidangan. Contohnya putusanputusan hakim yang memeriksa, mengadili, dan memutus kasus tindak pidana korupsi yang merugikan keuangan negara. Masyarakat banyak mengeluhkan berbagai problem putusan hakim di Pengadilan Tindak Pidana Korupsi yang tidak sesuai dengan bukti-bukti yang muncul di persidangan dan berujung pada pengabaian nilai keadilan terutama berkaitan dengan tuntutan pengembalian kerugian negara. Salah satu contohnya adalah Putusan Nomor 62/Pid.Sus/ Tipikor/2013/PN.PBR.

Duduk perkara dalam kasus ini dimulai sejak adanya penganggaran pengadaan komputer di Kec. Rengat, Kec. Pasir Penyu, Kec. Peranap, Kec. Batang, dan pengadaan peralatan jaringan 
komputer di Kec. Batang Gangsal, Kec. Lirik, Kec. Lubuk Batu Jaya, dan Kec. SeiLala, Kabupaten Indragiri Hulu. Dalam dakwaan kasus korupsi ini berawal dari adanya kegiatan pembangunan tower sebagai pengembangan dan pengoperasian KTP SIAK senilai Rp767.898.000,- sesuai kontrak dana tersebut digunakan untuk belanja modal pengadaan tower dan komputer untuk empat kecamatan. Kemudian pada APBD perubahan tahun 2011 kembali dianggarkan kegiatan serupa untuk empat kecamatan yang berbeda dengan nilai Rp796.556.000,-, sesuai kontrak dana tersebut digunakan untuk modal pengadaan tower.

Persoalan hukum muncul ketika beberapa item pekerjaan dan pembelian alat yang sudah dianggarkan ternyata tidak dilaksanakan oleh pihak kontraktor pemenang tender, padahal dalam laporan alat-alat tersebut sudah dibeli dan dipasang di delapan kecamatan. Begitu juga panitia pelaksana kegiatan yang menerima barang, mereka hanya tinggal tanda tangan atas perintah terdakwa Z. Rangkaian kegiatan ini memunculkan adanya dugaan penyalahgunaan wewenang antara $\mathrm{Z}, \mathrm{M}$, bersama-sama dengan pemenang tender.

Perkara ini menjerat Kepala Dinas Kependudukan dan Catatan Sipil Z dan H selaku pemenang tender yang telah divonis bersalah dan berkekuatan hukum tetap. Selanjutnya juga melibatkan M selaku Kasubbag. Umum Dinas Kependudukan dan Pencatatan Sipil Kabupaten Indragiri Hulu periode tahun 2011 selaku Pejabat Pelaksana Teknis Kegiatan. Bahwa dalam dakwaannya penuntut umum telah berupaya membuktikan kepada hakim untuk menjatuhkan sanksi pidana sekaligus membayar uang pengganti, karena di persidangan penuntut umum berhasil menunjukkan bukti adanya kerugian pada APBD Kabupaten Indragiri Hulu sejumlah Rp960.386.000,-.

Hakim dalam pertimbangan Putusan Nomor 62/Pid.Sus/Tipikor/2013/PN.PBR mencantumkan bahwa unsur kerugian negara telah dibuktikan di persidangan oleh penuntut umum melalui laporan Badan Pengawasan Keuangan dan Pembangunan Provinsi Riau, tetapi hakim mengabaikan laporan tersebut dan tidak menjatuhkan pidana pembayaran uang pengganti kepada terdakwa. Fakta persidangan ini memicu lahirnya problematika asset recovery, di mana seseorang yang sepatutnya mempertanggungjawabkan perbuatan pidana yang menimbulkan kerugian negara tetapi pengadilan membebaskannya dari kewajiban untuk mengganti kerugian tersebut. Padahal dalam hukum pidana jika terdapat kesalahan (opzet) maka pembuat tindak pidana harus bertanggung jawab (Sinta, 2017: 24).

Hakim juga membenarkan dan menyatakan laporan Badan Pengawasan Keuangan dan Pembangunan Provinsi Riau Nomor SR-4078/ PW04/5/2012 dinyatakan sah di persidangan. Mestinya putusan akhirnya akan mengikuti sebagaimana pertimbangan hukum yang diuraikan sebelumnya, tetapi nampaknya dalam putusan tersebut terjadi pertentangan antara pertimbangan dengan putusan akhir. Meskipun pidana uang pengganti dalam hukum positif kedudukannya hanya sebagai pidana tambahan, di mana hakim tidak wajib menjatuhkannya, namun demikian pidana uang pengganti layak dijatuhkan bilamana pelaku tindak pidana korupsi dalam persidangan terbukti memenuhi unsur-unsur yang telah ditentukan dalam Pasal 2 atau 3 Undang-Undang Nomor 31 Tahun 1999 jo. Undang-Undang Nomor 20 Tahun 2001 tentang Pemberantasan Tindak Pidana Korupsi, tetapi 
kekuasaan penjatuhannya sangat ditentukan oleh kehendak sang hakim yang mengadili, memeriksa, dan memutus.

Putusan ini dalam pandangan masyarakat setempat tidak merefleksikan rasa keadilan dan tidak memberi maslahat bagi warga Kabupaten Indragiri Hulu karena sekalipun pelaku dijatuhi pidana penjara, tetapi persoalan Sistem Informasi AdministrasiKependudukan(SIAK)di Kabupaten Indragiri Hulu belum terselesaikan karena dalam penganggarannya terjadi penyimpangan.

\section{B. Rumusan Masalah}

1. Apakah Putusan Nomor 62/Pid.Sus/ Tipikor/2013/PN.PBR telah berorientasi pada pemulihan (restorasi) kerugian negara yang menjadi korban tindak pidana korupsi?

2. Bagaimana problematika asset recovery dalam pengembalian aset akibat tindak pidana korupsi?

\section{Tujuan dan Kegunaan}

1. Untuk mengetahui dan mengkaji Putusan Nomor 62/Pid.Sus/Tipikor/2013/PN.PBR telah berorientasi pada pemulihan (restorasi) kerugian negara yang menjadi korban tindak pidana korupsi.

2. Untuk mendeskripsikan problematika asset recovery dalam pengembalian aset akibat tindak pidana korupsi.

\section{Tinjauan Pustaka}

\section{Tindak Pidana Korupsi}

Korupsi merupakan salah satu jenis kejahatan kerah putih (white collar crime) atau kejahatan berdasi. Berbeda dengan kejahatan konvensional yang melibatkan pelaku jalanan (street crime, blue collar crime, blue jeans crime), terhadap white collar crime ini, pihak yang terlibat adalah mereka orang-orang yang terpandang dalam masyarakat dan biasanya berpendidikan tinggi. Modus operandi white collar crime ini dilakukan dengan cara-cara canggih, bercampur dengan teori-teori ilmu pengetahuan seperti akuntansi dan statistik. Jika diukur dari canggihnya modus operandi, kelas orang yang terlibat dan besaran dana yang dijarah, jelas korupsi merupakan kejahatan kelas tinggi, yang sebenarnya dilatarbelakangi oleh prinsip yang keliru yaitu gredy is beautiful (kerakusan itu indah) (Fuady, 2004: 2).

Korupsi berasal dari bahasa Latin yaitu corruption dari kata kerja corrumpere berarti busuk, rusak, menggoyahkan, memutar balik, menyogok. Menurut Transparency International, korupsi adalah perilaku pejabat publik, baik politikus/politisi maupun pegawai negeri, yang secara tidak wajar dan tidak legal memperkaya diri atau memperkaya mereka yang dekat dengannya, dengan menyalahgunakan kekuasaan publik yang dipercayakan kepada mereka (Shoim, 2009: 14).

Baharudin Lopa mengemukakan tindak pidana korupsi adalah tindak pidana yang dilakukan dengan penyuapan manipulasi dan perbuatan-perbuatan melawan hukum yang merugikan atau dapat merugikan keuangan negara atau perekonomian negara, merugikan kesejahteraan atau kepentingan rakyat (Berdiansyah, 2017: 92).

Lubis \& Scott memandang korupsi adalah tingkah laku yang menguntungkan kepentingan diri sendiri dengan merugikan orang lain, oleh para pejabat pemerintah yang langsung 
melanggar batas-batas hukum atas tingkah laku tersebut (Hafidz, 2015: 6). Klitgaard melihat korupsi sebagai tingkah laku yang menyimpang dari tugas resmi sebuah jabatan negara karena keuntungan status atau uang yang menyangkut pribadi (perorangan, keluarga dekat, kelompok sendiri) yang melanggar aturan (Hafidz, 2015: 4). Secara umum korupsi dipahami sebagai suatu tindakan pejabat publik yang menyelewengkan kewenangan untuk kepentingan pribadi, keluarga, kroni, dan kelompok yang mengakibatkan kerugian negara.

Korupsi adalah kejahatan kalkulasi yang menggunakan pikiran bukan didorong oleh emosi. Pemahaman terhadap aspek-aspek korupsi serta penyebabnya dalam konteks situasi tertentu, menjadikan reformasi anti korupsi dapat dilakukan. Gerakan ini dilakukan melalui dua tahap. Pertama, merumuskan kebijaksanaan untuk menangani penyebab korupsi. Kedua, menciptakan kemauan politik (political will) yang sangat krusial bagi gerakan reformasi anti korupsi (Nugroho, 2014: 541). Korupsi mesti segera diatasi dengan berbagai cara yang rasional dan terukur (Santoso, 2013: 403).

\section{Teori Pengembalian Aset}

Dalam tindak pidana korupsi sebagai kejahatan luar biasa (extra ordinary crime) mewajibkan negara melalui penegak hukum untuk bertanggung jawab mengembalikan kerugian ekonomi yang ditimbulkan akibat tindak pidana korupsi yang didasarkan pada keadilan sosial. Teori dan tanggung jawab negara untuk mewujudkan keadilan sosial, memberikan justifikasi moral bagi negara untuk melakukan upaya-upaya pengembalian aset hasil tindak pidana korupsi. Teori keadilan sosial memberikan landasan moral bagi justifikasi pengembalian aset negara seperti yang dikemukakan oleh Michael Levi, yaitu:

a. Alasan pencegahan (prophylactic), yaitu untuk mencegah pelaku tindak pidana memiliki kendali atas asetaset yang diperoleh secara tidak sah untuk melakukan tindakan lain di masa yang akan datang;

b. Alasan kepatutan (propriety), yaitu pelaku tindak pidana tidak punya hak yang pantas atas aset-aset yang diperoleh secara tidak sah tersebut;

c. Alasan prioritas/mendahului, yaitu karena tindak pidana memberi prioritas kepada negara untuk menuntut aset yang diperoleh secara tidak sah daripada hak yang dimiliki oleh pelaku tindak pidana;

d. Alasan kepemilikan (proprietary), yaitu karena aset tersebut diperoleh secara tidak sah, maka negara memiliki kepentingan selaku pemilik aset tersebut (Yanuar, 2015: 101).

Pengembalian aset merupakan salah satu tujuan pemidanaan yang baru dalam hukum pidana pemberantasan tindak pidana korupsi dan tindak pidana pencucian uang. Untuk menjelaskan teori pengembalian aset perlu terlebih dahulu dikemukakan pengertian dan prinsip-prinsip yang mendasari teori pengembalian aset.

Menurut Matthew H Fleming, dalam dunia internasional, tidak ada pengertian pengembalian aset yang disepakati bersama. Fleming sendiri tidak mengemukakan rumusan definisi, tetapi menjelaskan bahwa pengembalian aset adalah proses pelaku-pelakukejahatan dicabut, dirampas, dihilangkan haknya dari hasil tindak pidana. Pendapat Fleming tersebut lebih menekankan pada tiga faktor, yaitu: pertama, pengembalian aset sebagai proses pencabutan, perampasan, penghilangan; kedua, yang dicabut, dirampas 
dan dihilangkan adalah hasil/keuntungan yang diperoleh dari tindak pidana korupsi; dan ketiga, salah satu tujuan pencabutan, perampasan, penghilangan adalah agar pelaku tindak pidana tidak dapat menggunakan hasil/keuntungankeuntungan dari tindak pidana sebagai alat/sarana untuk melakukan tindak pidana lainnya (Yanuar, 2015: 102).

Menurut Fleming, dari perspektif pemberantasan tindak pidana korupsi, pengembalian aset umumnya dianggap sebagai alat atau sarana untuk memerangi tindak pidana yang berorientasi pada keuntungan, termasuk tindak pidana akuisitif (tindak pidana yang didorong oleh nafsu keserakahan) dan tindak pidana terorganisasi. Dalam praktik dan dalam istilah yang paling umum pengembalian aset hasil tindak pidana korupsi merupakan proses yang banyak tahapannya dan cabang dari sejumlah kompleksitas, meliputi sejumlah lembaga, termasuk polisi (dalam pengertian yang luas meliputi kepolisian, kejaksaan, pengadilan, kepabeanan, dan badan-badan investigasi lainnya).

Konvensi Anti Korupsi Tahun 2003 menunjukkan pengembalian aset merupakan prinsip dasar dari konvensi. Berdasarkan penelitian yang dilakukan, penulis menilai penting untuk menciptakan dan merumuskan teori hukum yang disebut teori pengembalian aset, sebab seperti yang dikatakan Oliver Wendel Holmes teori adalah bagian terpenting dari hukum, seperti layaknya seorang arsitek dalam membangun sebuah rumah, teori memberi bentuk, yang menurut Rudolf Von Jhering berakar pada esensi paling dalam dari hukum (Prasetyo, 2010: 88).

Teori pengembalian aset merupakan bagian terpenting dari hukum anti korupsi dalam bentuk yang berakar pada esensi paling dalam dari hukum anti korupsi, terutama dalam fungsinya mengupayakan pengembalian aset hasil tindak pidana korupsi kepada negara, mencegah pelaku melakukan tindak pidana lain dengan menggunakan aset tersebut. Teori pengembalian aset adalah teori hukum yang menjelaskan sistem hukum pengembalian aset berdasarkan prinsip-prinsip keadilan sosial yang memberikan kemampuan, tugas, dan tanggung jawab kepada institusi negara dan institusi hukum untuk memberikan perlindungan dan peluang kepada individu-individu dalam masyarakat untuk mencapai kesejahteraan.

Teori ini dilandaskan pada prinsip dasar "berikan kepada negara apa yang menjadi haknya." Dalam hak negara terkandung kewajiban yang menjadi hak individu warga negara, sehingga prinsip tersebut setara dengan prinsip "berikan kepada rakyat apa yang menjadi haknya." Pada hakiktanya adil bermakna menempatkan sesuatu pada tempatnya dan memberikan kepada siapa saja apa yang menjadi haknya. (Ravena \& Kristian, 2017: 179)

Teori pengembalian aset merupakan upaya untuk menghadirkan keadilan ekonomi. Keadilan dalam konteks putusan hakim dapat dilihat dari dua sisi yaitu keadilan prosedural dan keadilan substantif. Keadilan prosedural adalah keadilan terkait dengan perlindungan hak asasi manusia, dan hak-hak hukum para pihak (tersangka, terdakwa, saksi, dan korban) dalam setiap proses tahapan peradilan yang diatur oleh undang-undang. Keadilan substantif adalah keadilan terkait dengan putusan hakim dalam memeriksa, mengadili, dan memutus suatu perkara yang didasarkan pada pertimbangan kejujuran, objektif, dan sesuai dengan hati nurani (Syamsudin, 2012: 41). 


\section{Teori Penjatuhan Putusan Hakim}

Selanjutnya menurut Mackenzine (Manan, 2006: 7) ada beberapa teori yang dipergunakan oleh hakim dalam mempertimbangkan penjatuhan putusan yaitu sebagai berikut:

a. Teori Keseimbangan

Teori keseimbangan menjelaskan bahwa dalam menjatuhkan putusan hakim harus mempertimbangkan keseimbangan antara syarat-syarat yang ditentukan oleh undangundang dan kepentingan pihak-pihak yang tersangkut dan berkaitan dengan perkara antara lain, seperti keseimbangan antara pelaku dengan masyarakat, kepentingan pelaku dan kepentingan korban.

b. Teori Pendekatan Seni dan Intuisi

Penjatuhan putusan oleh hakim merupakan diskresi atau kewenangan dari hakim. Sebagai diskresi dalam menjatuhkan putusan hakim menyesuaikan dengan keadaan dan pidana yang wajar bagi setiap pelaku tindak pidana, hakim akan melihat keadaan pihak terdakwa atau penuntut umum.

c. Teori Pendekatan Keilmuan

Titik tolak dari teori ini adalah pemikiran bahwa proses penjatuhan pidana harus dilakukan secara sistematik dan penuh kehati-hatian, khususnya dalam kaitannya dengan putusan-putusan terdahulu dalam rangka menjamin konsistensi dari putusan hakim. Pendekatan keilmuan ini merupakan semacam peringatan bahwa dalam memutus suatu perkara, hakim tidak boleh semata-mata atas dasar intuisi atau insting semata, tetapi harus dilengkapi dengan ilmu pengetahuan hukum dan juga wawasan keilmuan hakim dalam menghadapi suatu perkara yang harus diputusnya.

d. Teori Pendekatan Pengalaman

Pengalaman dari seorang hakim merupakan hal yang dapat membantunya dalam menghadapi perkara-perkara yang dihadapinya sehari-hari. Dengan pengalaman yang dimilikinya, seorang hakim dapat mengetahui bagaimana dampak dari putusan yang dijatuhkan dalam suatu perkara pidana yang berkaitan dengan pelaku, korban maupun masyarakat.

\section{e. Teori Ratio Decidendi}

Teori ini didasarkan pada landasan filsafat yang mendasar dan mempertimbangkan segala aspek yang berkaitan dengan pokok perkara yang disengketakan, kemudian mencari peraturan perundang-undangan yang relevan dengan pokok perkara yang disengketakan sebagai dasar hukum dalam penjatuhan putusan, serta pertimbangan hakim harus didasarkan pada motivasi yang jelas untuk menegakkan hukum dan memberikan keadilan bagi para pihak yang berperkara. Pasal 53 ayat (1) dan (2) Undang-Undang Nomor 48 Tahun 2009 tentang Kekuasaan Kehakiman yang menyatakan bahwa "dalam memeriksa dan memutuskan perkara, hakim bertanggung jawab atas penerapan putusan yang dibuatnya."

Putusan tersebut harus memuat pertimbangan hakim yang didasarkan pada alasan dan dasar hukum yang tepat dan benar. Adanya Undang-Undang Nomor 48 Tahun 2009 membuat kebebasan 
hakim menjadi semakin besar, atau dapat dikatakan bahwa hakim tidak hanya dapat menetapkan tentang hukumnya, tetapi hakim dapat menemukan hukumnya.

Hakim dalam menjatuhkan putusan, akan menggunakan berbagai pendekatan sebagaimana diuraikan di atas dan berdasarkan alat bukti yang cukup serta keyakinannya. Perlu diketahui bahwa sebelummengeluarkan putusan, hakim harus mengetahui tingkat kesalahan pelaku dan akibat yang ditimbulkan dari kesalahannya. Asas "tidak dipidana jika tidak ada kesalahan," merupakan dasar dipidananya si pembuat. Apabila pelaku tidak dapat dipertanggungjawabkan, walaupun perbuatannya telah memenuhi unsur-unsur rumusan delik, pelaku harus dilepaskan dari segala tuntutan hukum. Orang yang dapat dituntut di muka pengadilan dan dijatuhi pidana haruslah melakukan tindak pidana dengan "kesalahan."

\section{METODE}

Metode penelitian ini menggunakan penelitian hukum normatif (yuridis normatif) dengan menganalisis Putusan Nomor 62/Pid.Sus/ Tipikor/2013/PN.PBR sebagai objek penelitian yang dikaji dengan menggunakan konsep, teori, dan peraturan perundang-undangan yang berlaku.

\section{HASIL DAN PEMBAHASAN}

A. Kajian Putusan Nomor 62/Pid.Sus/ Tipikor/2013/PN.PBR Kaitannya dengan Pengembalian Kerugian Daerah Sebagai Korban Tindak Pidana Korupsi

Perjalanan kasus ini dimulai pada tahun 2013 di lingkungan Pengadilan Tindak Pidana
Korupsi pada Pengadilan Negeri Pekanbaru yang memeriksa, mengadili, dan memutus kasus tindak pidana korupsi yang dilakukan oleh $\mathrm{M}$ seorang pegawai negeri yang menjabat sebagai Kasubbag. Umum pada Dinas Kependudukan dan Pencatatan Sipil Kabupaten Indragiri Hulu periode tahun 2011.

Madalah PejabatPelaksana Teknis Kegiatan yang diangkat berdasarkan Surat Keputusan Kepala Dinas Kependudukan dan Pencatatan Sipil Kabupaten Indragiri Hulu Nomor KEP/09/ DKPS/XI/2011 tanggal 1 November 2011, yang melakukan atau turut serta melakukan dengan saksi Z (penuntutan dilakukan secara terpisah/ mempunyai kekuatan hukum tetap/inkracht) selaku Kepala Dinas Kependudukan dan Pencatatan Sipil Kabupaten Indragiri Hulu yang diangkat berdasarkan Surat Keputusan Bupati Indragiri Hulu Nomor 225/X/2010 tanggal 6 Oktober 2010 selaku Pengguna Anggaran, dalam Kegiatan Pengembangan dan Pengoperasian Sistem Informasi Administrasi Kependudukan (SIAK) Secara Terpadu Kabupaten Indragiri Hulu pada APBD Kabupaten Indragiri Hulu tahun 2011.

M selaku terdakwa dituntut oleh jaksa penuntut umum dengan Pasal 2 dan 3 UndangUndang Nomor 31 Tahun 1999 sebagaimana diubah dengan Undang-Undang Nomor 20 Tahun 2001 tentang Pemberantasan Tindak Pidana Korupsi, karena telah melakukan perbuatan melawan hukum berupa penyalahgunaan kewenangan, kesempatan, atau sarana yang ada padanya karena jabatan atau kedudukan yang dapat merugikan keuangan negara atau perekonomian negara.

Pemikiran yang berhubungan dengan perbuatan melawan hukum dengan kerugian 
keuangan negara selalu didasarkan pada prinsip, bahwa setiap perbuatan yang melawan hukum dan menimbulkan kerugian keuangan negara mewajibkan orang yang menimbulkan kerugian itu karena kesalahannya untuk menggantikan kerugian keuangan negara tersebut. Menurut Minarno dalam tindak pidana korupsi unsur melawan hukum adalah genus-nya, sedangkan unsur menyalahgunakan wewenang adalah species-nya. Dengan demikian, setiap perbuatan penyalahgunaan wewenang sudah pasti melawan hukum (Minarno, 2009: 16).

Hubungan kausalitas antara perbuatan melawan hukum dan kerugian keuangan negara seringkali menjadi perdebatan antara jaksa penuntut umum dengan tim pembela dalam tindak pidana korupsi. Ilmu hukum mengenal bermacam-macam doktrin dan teori mengenai hubungan kausalitas, seperti ajaran atau teori conditio sine qua non dari Von Buri dan teori adequat. Teori conditio sine qua non menjelaskan hubungan yang sangat luas, sedangkan teori adequat akibat yang timbul harus seimbang dengan perbuatan yang menjadi penyebabnya (Latief, 2014: 299).

Penerapanhukumkerugiankeuangannegara dalam hubungan dengan tindak pidana korupsi yang harus dibuktikan adalah adanya kerugian keuangan negara yang mempunyai hubungan kausal dengan perbuatan terdakwa. Dalam perspektif hakim, pembuktian adanya kerugian keuangan negara didasarkan pada hal-hal yang relevan secara yuridis yang muncul secara sah di persidangan, antara lain perhitungan atau hasil audit investigasi dari pihak yang berkompeten, misalnya Badan Pemeriksa Keuangan dan Badan Pengawasan Keuangan dan Pembangunan, atau instansi resmi yang memiliki keahlian dalam hal menentukan kerugian keuangan negara.
Bukti atau keterangan yang bersifat instansional akan lebih meyakinkan dibandingkan dengan yang bersifat personal dan secara teori bukti itu menunjukan adanya hubungan kausal dari sebab ke akibat (Alkostar, 2008: 36).

Penentuan kerugian negara dalam praktik peradilan tindak pidana korupsi seringkali menimbulkan perdebatan. Penentuan ada atau tidaknya kerugian negara dan berapa jumlahnya, dalam praktik masing-masing lembaga memiliki perhitungan yang berbeda-beda. Perhitungan yang dilakukan oleh Badan Pemeriksa Keuangan sering berbeda hasilnya dengan perhitungan penyidik kejaksaan atau Komisi Pemberantasan Korupsi. Persoalannya lembaga mana yang dapat dijadikan acuan untuk menentukan kerugian negara.

Merujuk pada Undang-Undang Badan Pemeriksa Keuangan dan Keputusan Presiden Nomor 103 Tahun 2001 tentang Kedudukan, Tugas, Fungsi, Kewenangan, Susunan Organisasi dan Tata Kerja Lembaga Pemerintah Non Departemen menentukan, bahwa yang menilai/ menetapkan ada tidaknya kerugian keuangan negara adalah Badan Pemeriksa Keuangan dan Badan Pengawasan Keuangan dan Pembangunan. Adapun perhitungan kerugian keuangan negara sendiri bersifat kasuistis, atau dilihat kasus per kasus.

Badan Pemeriksa Keuangan bukanlah satusatunya lembaga yang berwenang melakukan audit perhitungan kerugian keuangan negara dalam rangka pembuktian suatu tindak pidana korupsi. Akan tetapi, perhitungan kerugian keuangan negara juga dapat dilakukan oleh ahli lainnya seperti akuntan publik, demikian juga Badan Pengawasan Kenuangan dan Pembangunan atas permintaan dari penyidik. 
Bahkan apabila penyidik dan jaksa penuntut umum memiliki kemampuan untuk melakukan penghitungan, juga dapat menghitung sendiri kerugian negara akibat korupsi.

Hal tersebut didasarkan pada Putusan Mahkamah Konstitusi Nomor 31/PUU-X/2012. Aswidjon menjelaskan putusan Mahkamah Konstitusi itu membenarkan bahwa Komisi Pemberantasan Korupsi bukan hanya dapat berkoordinasi dengan Badan Pemeriksa Keuangan dan Badan Pengawasan Keuangan dan Pembangunan dalam rangka pembuktian tindak pidana korupsi, melainkan dapat pula berkoordinasi dengan instansi lain. Bahkan Komisi Pemberantasan Korupsi bisa membuktikan sendiri atau mengundang ahli.

Penerapan hukum kerugian keuangan negara dalam Putusan Nomor 62/Pid.Sus/ Tipikor/2013/PN.PBR menurut penulis telah terdapat kekhilafan secara nyata yang dilakukan oleh hakim, karena menurut data dan informasi yang diperoleh dalam pertimbangan putusan tersebut menyatakan:

Bahwa akibat dari perbuatan terdakwa $\mathrm{M}$ bersama-sama dengan saksi $\mathrm{Z}$ telah mengakibatkan kerugian Keuangan Negara Cq. Dinas Kependudukan dan Pencatatan Sipil Kab. Indragiri Hulu sejumlah Rp960.386.000,- yaitu pada kegiatan Belanja Modal Pengadaan Komputer untuk empat lokasi di Kec. Rengat, Kec. Pasir Penyu, Kec. Peranap, Kec. Batang Peranap dengan pagu anggaran sebesar Rp945.812.200,- (APBD murni tahun 2011), terjadi kerugian negara sebesar Rp533.136.000,-

Bahwa Belanja Modal Pengadaan Peralatan Jaringan Komputer untuk empat lokasi di Kec. Batang Gangsal, Kec. Lirik, Kec. Lubuk Batu Jaya dan Kec. SeiLala dengan pagu anggaran sebesar Rp861.266.000,(APBD perubahan tahun 2011) terjadi kerugian negara sebesar Rp427.250.000,-
Bahwa dalam pelaksanaan kegiatan pengembangan dan pengoperasian KTP SIAK ditemukan beberapa item pekerjaan dan pembelian alat yang sudah dianggarkan ternyata tidak dilaksanakan oleh kontraktor pelaksana, sementara dalam laporannya alat-alat tersebut sudah dibeli dan dipasang.

Bahwa terdakwa $M$ selaku Pejabat Pelaksana Kegiatan Teknis selaku panitia penerima barang langsung menandatangani berkas penerimaan barang yang sudah disiapkan pegawai Disdukcapil atas perintah $\mathrm{Z}$ tanpa melakukan verifikasi data terlebih dahulu.

Bahwa menurut keterangan terdakwa $\mathrm{Z}$ yang dilakukan penuntutan secara terpisah, mantan Kadisdukcapil Kabupaten Inhu mengakui bahwa dirinya bersamasama $\mathrm{H}$ selaku kontraktor sepakat untuk mengurangi spesifikasi, yakni besi dan tinggi tower dari yang seharusnya 75 meter dan menggunakan besi $40 \mathrm{~cm}$ x 40 $\mathrm{cm}$, sehingga pembangunan tower SIAK tidak sesuai spesifikasi yang ada dalam kesepakatan.

Bahwa pada tanggal 19 Desember 2012 sesuai dengan Laporan Hasil Perhitungan Kerugian Keuangan Negara dari Badan Pengawasan Keuangan dan Pembangunan Perwakilan Provinsi Riau Nomor SR4078/PW04/5/2012 yang ditandatangani oleh $\mathrm{M}$ sebagai kepala perwakilan, $\mathrm{K}$ sebagai pembantu penanggung jawab, MH sebagai pengendali teknis, AS sebagai ketua tim, dan HP sebagai anggota tim, dengan kesimpulan sebagai berikut: jumlah kerugian negara atas dugaan tindak pidana korupsi sejumlah Rp960.386.000,- atau setidak-tidaknya sekitar jumlah tersebut.

Berdasarkan pertimbangan tersebut ada beberapa fakta yang menunjukkan adanya perbuatan pidana yang mengakibatkan kerugian daerah yang muncul di persidangan yaitu:

1. Beberapa item pekerjaan dan pembelian alat sudah dianggarkan tetapi tidak dilaksanakan, sementara dalam laporan item tersebut telah dibeli dan dipasang. 
2. Terdakwa $\mathbf{M}$ dengan sengaja langsung menandatangani dokumen penerimaan barang/jasa tanpa melakukan verifikasi terhadap kebenarannya.

3. Adanya pengurangan spesifikasi bangunan tower dan bahan yang digunakan tidak sesuai dengan kesepakatan.

4. Adanya laporan Badan Pengawasan Keuangan dan Pembangunan Provinsi Riau bahwa dugaan tindak pidana korupsi pembangunan tower dan komputer di delapan kecamatan Kabupaten Indragiri Hulu merugikan keuangan daerah sebesar Rp960.386.000,-

Informasi mengenai fakta tersebut muncul dalam pertimbangan hakim dan diakui oleh terdakwa M, maka sudah sewajarnya informasi ini menjadi bagian penting yang tidak bisa dipisahkan dalam kontruksi hukum yang dibuat oleh hakim dalam merumuskan putusannya.

Proses pembuatan putusan pengadilan yang berkualitas selalu mencerminkan kepiawaian dan kemampuan hakim dalam memutus perkara. Putusan pengadilan yang berkualitas selalu mencerminkan eksistensi bahwa hakim yang memutus juga berkualitas. Bagi pencari keadilan putusan pengadilan berkualitas adalah putusan yang dapat mewujudkan keadilan atau putusan yang mencerminkan rasa keadilan yang dapat dilaksanakan dan diterima atau memberikan kepuasan pencari keadilan.

Hakim dalam merumuskan putusan tidak mempertimbangkan hasil perhitungan kerugian keuangan negara dari Badan Pengawasan Keuangan dan Pembangunan Provinsi Riau Nomor SR-4078/PW04/5/2012. Laporan ini merupakan bukti dokumen (surat) yang menunjukkan adanya perbuatan melawan hukum berupa penyalahgunaan wewenang yang dilakukan terpidana $\mathrm{M}$ bersama-sama dengan Z Kepala Dinas Kependudukan dan Pencatatan Sipil Kabupaten Indragiri Hulu periode tahun 2011, di mana $M$ bertugas selaku Pejabat Pelaksana Teknis Kegiatan yang mengakibatkan kerugian keuangan negara secara nyata dan pasti jumlahnya karena dalam laporan Badan Pengawasan Keuangan dan Pembangunan nilai kerugiannya disebutkan secara jelas.

Problem asset recovery yang mengemuka dalam putusan ini baik Z selaku Kepala Dinas Indragiri Hulu maupun $M$ selaku Pejabat Pelaksana Teknis Kegiatan telah dilakukan penuntutan secara terpisah tidak dijatuhi pidana uang pengganti, sebagaimana temuan Badan Pengawasan Keuangan dan Pembangunan Provinsi Riau yang menunjukkan adanya kerugian APBD sejumlah Rp960.386.000,-Padahal Pasal 18 ayat (1) hurufb Undang-Undang Nomor 31 Tahun 1999 tentang Pemberantasan Korupsi memberikan kewenangan bagi hakim untuk menjatuhkan pidana uang pengganti kepada terdakwa apabila terbukti secara sah dan meyakinkan telah merugikan keuangan negara.

Setiap putusan hakim secara yuridis formal tetap tidak dapat mengabaikan aspek prosedural, namun yang terpenting dari itu semua adalah lahirnya suatu putusan yang dapat mengantarkan para hakim untuk sampai pada tujuan hukum yang sesungguhnya yaitu berkeadilan, bermanfaat, dan berkepastian hukum. (Anshar, 2018 : 157)

Menurut teori hukum pidana, penyalahgunaan wewenang yang dilakukan oleh terpidana $\mathrm{M}$ adalah sebuah bentuk kesalahan, di mana kesalahan adalah salah satu dasar munculnya tuntutan pertanggungjawaban pidana 
yang bersumber dari asas besar bahwa "geen straf zonder schuld" atau (tiada pidana tanpa kesalahan). Amar putusan berupa pemidanaan terhadap terpidana sudah dijatuhkan, tetapi persoalan yang berkaitan dengan kerugian ekonomi negara sebesar Rp 960.386.000,- tidak dipandang sebagai sebuah fakta persidangan yang mendukung hakim untuk menjatuhkan pidana uang pengganti. Patut dicatat bahwa dalam teori yang dikemukakan Mackenzine ada beberapa pertimbangan yang wajib diperhatikan hakim sebelum menjatuhkan putusan antara lain:

1. Faktor keseimbangan yang menjelaskan bahwa dalam menjatuhkan putusan hakim harus mempertimbangkan keseimbangan kepentingan pihak-pihak yang ada dalam perkara tersebut seperti pelaku, korban. dan masyarakat. Penulis melihat dalam Putusan Nomor 62/Pid.Sus/Tipikor/2013/PN.PBR, hakim mengabaikan aspek keseimbangan kepentingan pelaku dan korban (Kabupaten Indragiri Hulu), karena mengabaikan fakta sekaligus bukti surat berupa laporan Badan Pengawasan Keuangan dan Pembangunan tentang adanya kerugian yang riil. Padahal seharusnya bukti tersebut menjadi dasar hakim untuk menjatuhkan putusan pidana uang pengganti walaupun terpidana tidak menikmatinya, karena undang-undang tidak mensyaratkan terpidana harus menikmatinya. Hal ini sebagai konsekuensi hukum akibat perbuatan melawan hukum yang diperbuatnya.

2. Faktor pengalaman seorang hakim semestinya menggunakan pendekatan pengalaman untuk mengetahui modus dan strategi terpidana untuk mengalihkan aset hasil korupsi agar ia lolos dari kewajiban membayar uang pengganti.
Dengan pengalamannya seorang hakim dapat mengetahui bagaimana dampak dari putusan yang dijatuhkan dalam suatu perkara pidana yang berkaitan dengan pelaku, korban maupun masyarakat. Penulis berpendapat bahwa hakim tidak menggunakan pengalaman dan instuisinya untuk mengetahui siapa yang menikmati aliran dana sebesar Rp960.386.000,yang menyebabkan negara merugi, yang berdampak pada buruknya pelayanan administrasi di delapan kecamatan yang memiliki proyek pengadaan komputer dan pengadaan jaringan komputer di Kabupaten Indragiri Hulu.

Dikaji dari perspektif teori kausalitas (teori sebab akibat) munculnya kerugian keuangan daerah di Kabupaten Indragiri Hulu disebabkan adanya penyalahgunaan wewenang yang dilakukan oleh terpidana sebagai pejabat yang berwenang mengatur proyek pengadaan komputer dan pengadaan alat jaringan komputer (tower), sehingga sepatutnya terpidana harus dapat mempertanggungjawabkan dampak dari tindak pidana korupsi bukan hanya sebatas pidana penjara dan denda melainkan memulihkan (merestorasi) kerugian materiil Kabupaten Indragiri Hulu.

Upaya pengembalian aset (asset recovery) tidak nampak dalam Putusan Nomor 62/Pid. Sus/Tipikor/2013/PN.PBR. Pengembalian aset merupakan suatu upaya pemulihan hak korban dalam hal ini Kabupaten Indragiri Hulu untuk menerima kembali kerugian materiil yang diderita pasca terjadi tindak pidana korupsi. Pengembalian aset berakar dari keadilan restorative karena paradigma retributive justice saat ini sudah mulai banyak ditinggalkan. Keadilan restorative menuntut adanya pemulihan 
hak (keadaan) seperti semula seperti sebelum terjadinya korupsi. Putusan pengadilan untuk memulihkan keadaan yang semula tidak adil, karena pelanggaran hukum ke keadaan semula (restitutio in integrum) itulah puncak dari penegakan hukum (Triningsih, 2015: 136).

Instrumen yang digunakan dalam pengembalian keadaan seperti semula ini melalui pidana tambahan berupa pidana uang pengganti. Pidana uang pengganti dipandang sebagai sebuah kemajuan dari segi politik hukum karena menunjukan adanya kemauan negara untuk mengembalikan uang negara yang hilang/berkurang akibat tindak pidana korupsi (Mahmud, 2017: 139). Meskipun demikian pengembalian aset sulit dilaksanakan karena hakim tidak menjatuhkan pidana uang pengganti atau dijatuhkan, tetapi disubsiderkan dengan pidana kurungan.

Putusan yang berorientasi pada pengembalian aset seharusnya dapat memenuhi tuntutan korban yang nyata-nyata dirampas tanpa hak dan melawan hukum. Setidaknya ada tiga hal menjadi tuntutan pengembalian aset, yaitu:

1. Pemulihan kerugian materiil akibat tindak pidana korupsi;

2. Putusan hakim mampu menghadirkan keseimbangan antara kepentingan pelaku, korban, dan masyarakat;

3. Putusan hakim dapat memberikan manfaat secara ekonomis bagi masyarakat.

Melihat beberapa pertimbangan yang menjadi sumber problem dalam Putusan Nomor 62/Pid.Sus/Tipikor/2013/PN.PBR, penulis tidak menemukan adanya kemahiran hakim dalam merekonstruksi fakta dalam persidangan dengan pengambilan putusan. Padahal kemampuan merekonstruksi fakta dalam menerapkan hukum yang dituangkan dalam putusan akan memberikan cerminan eksistensi hakim dalam merekonstruksi keadilan dan kemanfaatan yang dibutuhkan oleh masyarakat Kabupaten Indragiri Hulu.

Menakar nilai keadilan pengembalian aset (asset recovery) dalam Putusan Nomor 62/ Pid.Sus/Tipikor/2013/PN.PBR masih jauh dari harapan pencari keadilan (justitiabelen), karena kerugian yang hilang itu tidak dapat dikembalikan, padahal sangat berkaitan dengan kepentingan hajat hidup orang banyak di Kabupaten Indragiri Hulu. Dengan demikian harapan pengembalian aset dalam putusan hakim untuk mengembalikan hak-hak korban (Kabupaten Indragiri Hulu) yang menyangkut pelayanan administrasi di berbagai kecamatan belum terpenuhi.

\section{B. Problematika Pemulihan Aset dalam Pengembalian Aset Akibat Tindak Pidana Korupsi}

Pembuatan putusan oleh hakim merupakan proses yang kompleks dan penuh dengan dinamika dan problematika sehingga memerlukan pelatihan, pengalaman, dan kebijaksanaan. Menurut Alkostar, sebagai figur sentral penegak hukum para hakim memiliki kewajiban moral dan tanggung jawab profesional untuk menguasai knowledge, memiliki skill berupa legal technical capacity. Dengan adanya kecukupan pengetahuan dan keterampilan teknis para hakim dalam memutus suatu perkara, akan dapat memberikan pertimbangan hukum (legal reasoning) yang tepat dan benar. Jika suatu putusan pengadilan tidak cukup mempertimbangkan (onvoldoende gemotiveerd) tentang hal-hal yang relevan secara yuridis dan sah muncul di persidangan 
maka akan terasa adanya kejanggalan yang akan menimbulkan matinya akal sehat (Syamsudin, 2012: 41). Lebih jauh dimungkinkan adanya dugaan judicial corruption (Rahman, 2016: 4521).

Problematika yang muncul dalam upaya pemulihan aset (asset recovery) dalam perkara tindak pidana korupsi adalah mengenai putusan hakim yang berupaya menjatuhkan pidana tambahan berupa pembayaran uang pengganti, akan tetapi selalu dibenturkan dengan keadaan ekonomi terpidana yang tidak mampu untuk membayar lunas uang pengganti. Akibatnya pidana uang pengganti sebagai upaya asset recovery disubsiderkan dengan pidana penjara, sehingga putusan hakim tidak dapat mewujudkan harapan mencapai keadilan ekonomi.

\section{Menurut data Litbang Komisi} Pemberantasan Korupsi nilai kerugian negara akibat tindak pidana korupsi di Indonesia selama tahun 2003-2015 mencapai Rp153,01 triliun. Sedangkan jumlah hukuman finansial yang berhasil mengembalikan kerugian negara berupa denda, penyitaan aset, dan pembayaran uang pengganti hanya terkumpul Rp15.957.821.529.773,- atau sekitar 10,4\%. Total kerugian negara itu berasal dari 2.321 kasus yang melibatkan 3.109 terdakwa. Data ini menunjukkan bahwa hukuman finansial kepada para terpidana korupsi cenderung sub optimal, lebih rendah dari kerugian negara yang muncul akibat korupsi (Mas, 2015: 146).

Secara normatif ketentuan pembayaran pidana uang pengganti diatur dalam Pasal 18 Undang-Undang Nomor 31 Tahun 1999 tentang Pemberantasan Tindak Pidana Korupsi, yang mengatur tentang pidana tambahan sebagai usaha untuk pengembalian kerugian negara akibat korupsi yang menegaskan sebagai berikut:

(1) Selain pidana tambahan sebagaimana dimaksud dalam Kitab Undang-Undang Hukum Pidana, sebagai pidana tambahan adalah:

a. Perampasan barang bergerak yang berwujud atau yang tidak berwujud atau barang tidak bergerak yang digunakan untuk atau yang diperoleh dari tindak pidana korupsi, termasuk perusahaan milik terpidana di mana tindak pidana korupsi dilakukan, begitu pula harga dari barang yang menggantikan barang-barang tersebut.

b. Pembayaran uang pengganti yang jumlahnya sebanyak-banyaknya dengan harta benda yang diperoleh dari tindak pidana korupsi.

c. Penutupan seluruh atau sebagian perusahaan untuk waktu yang paling lama satu tahun.

d. Pencabutan seluruh atau sebagian hak-hak tertentu atau penghapusan seluruh atau sebagian keuntungan tertentu yang telah atau dapat diberikan oleh pemerintah kepada terpidana.

(2) Jika terpidana tidak membayar uang pengganti sebagaimana dimaksud dalam ayat (1) huruf b paling lama dalam waktu satu bulan sesudah putusan pengadilan yang telah memperoleh kekuatan hukum tetap, maka harta bendanya dapat disita oleh jaksa dan dilelang untuk menutupi uang pengganti tersebut.

(3) Dalam hal terpidana tidak mempunyai harta benda yang mencukupi untuk membayar uang pengganti sebagaimana dimaksud dalam ayat (1) huruf $b$, maka dipidana dengan pidana penjara yang lamanya tidak melebihi ancaman maksimum dari pidana pokoknya sesuai ketentuan dalam undang-undang ini dan lamanya pidana tersebut sudah ditentukan dalam putusan pengadilan.

Kaidah ini menunjukkan bahwa dasar hukum upaya pengembalian kerugian negara melalui pembayaran pidana uang pengganti telah ada. Kenyataan dalam praktik peradilan 
menunjukkan bahwa hakim telah menjatuhkan putusan pembayaran pidana uang pengganti sesuai dengan kerugian keuangan negara yang ditimbulkan akibat tindak pidana korupsi, namun saat akan dieksekusi jaksa, terpidana mengakui dirinya tidak memiliki harta yang cukup untuk membayar pidana uang pengganti, pada akhirnya pidana uang pengganti diganti dengan pidana penjara pengganti yang lamanya tidak melebihi pidana pokok yang dijatuhkan seperti ditentukan dalam Pasal 18 ayat (3) di atas. Putusan pengadilan seperti ini tidak mungkin mampu memulihkan kerugian negara (asset recovery) akibat tindak pidana korupsi dan tidak akan menimbulkan efek jera.

Putusan pengadilan untuk pidana uang pengganti selama ini mengacu pada Pasal 18 Undang-Undang Nomor 31 Tahun 1999 tentang Pemberantasan Tindak Pidana Korupsi. Bila dilihat dari paham positivistik-legalistik tidak menimbulkan persoalan karena hakim telah melaksanakan norma yang ada dalam undangundang dan telah memberikan kepastian hukum sebagaimana tujuan dari paham positivisme, namun jika dilihat dari paham sosiologis praktik ini menjadi suatu problematika pemidanaan karena pembayaran uang pengganti yang disubsiderkan dengan pidana penjara tidak memberikan keadilan ekonomi dan kemanfaatan bagi kepentingan negara. Sekalipun pelaku menjalani hukuman penjara, tetapi asetnya tidak berhasil dikembalikan pada negara, sehingga negara tetap mengalami kerugian.

Undang-Undang Pemberantasan Tindak Pidana Korupsi dibentuk berdasarkan asas yang melandasi dan menjiwai lahirnya berbagai norma dalam undang-undang korupsi. Asas merupakan norma hukum tidak tertulis yang hidup dan berkembang di dalam masyarakat dan menjadi spirit of norm dalam undang-undang korupsi. Salah satu asas tidak tertulis yang menjiwai undang-undang korupsi adalah asas "pengembalian kerugian negara (assetrecovery)" (Pardede, 2015: 236).

Realitas upaya pemulihan kerugian negara (asset recovery) tidak senafas dengan teori pengembalian aset (asset recovery) yang dilandaskan pada prinsip dasar bahwa "berikan kepada negara apa yang menjadi haknya.” Dalam hak negara terkandung kewajiban yang menjadi hak individu warga negara, sehingga prinsip tersebut setara dengan prinsip "berikan kepada rakyat apa yang menjadi haknya."

\section{Barda Nawawi Arief memaparkan} bahwa strategi kebijakan pemidanaan dalam kejahatan-kejahatan yang berdimensi baru harus memperhatikan hakikat permasalahan. Bila hakikat permasalahannya lebih dekat dengan masalah-masalah di bidang hukum perekonomian maka lebih diutamakan penggunaan pidana denda atau semacamnya. Penetapan sanksi pidana seharusnya dilakukan melalui pendekatan rasional. Bila berdasar pada konsep rasional ini, maka kebijakan penetapan sanksi pidana tidak terlepas dari penetapan tujuan yang ingin dicapai oleh kebijakan kriminal secara keseluruhan (Arief, 2009: 13).

Berdasarkan pendapat di atas, maka sepatutnya sanksi pidana yang diterapkan bagi terpidana korupsi adalah pidana yang berorientasi pada kerugian ekonomi negara, yaitu:

1. Perampasan barang bergerakyang berwujud atau yang tidak berwujud atau barang tidak bergerak yang digunakan untuk atau yang diperoleh dari tindak pidana korupsi;

2. Pembayaran uang pengganti; dan 
3. Penutupan seluruh atau sebagian perusahaan.

Jenis pidana semacam ini akan lebih menghadirkan keadilan ekonomi dan kemanfaatan ekonomi bagi negara yang menderita kerugian materiil. Namun demikian Pasal 18 ayat (3) Undang-Undang Nomor 31 Tahun 1999 tentang Pemberantasan Tindak Pidana Korupsi memberikan ruang bagi terpidana untuk lolos dari kewajiban membayar uang pengganti.

Ruang ini yang menjadi problematika dalam upaya pemulihan asset recovery karena secara empiris muncul berbagai putusan hakim yang disubsiderkan dengan pidana penjara, padahal sesungguhnya terpidana memiliki uang/ aset tersembunyi yang bisa dibayarkan untuk mengganti kerugian keuangan negara.

Uang haram yang berasal dari kejahatan korupsi tersebut praktiknya banyak disamarkan asal-usulnya untuk menghindari tindakan dari otoritas yang berwenang, terutama memasukkan uang tersebut ke dalam sistem keuangan (financial system) sehingga uang tersebut dapat dikeluarkan dari sistem keuangan itu sebagai uang yang halal (Setiadi, 2010: 154).

Problematika asset recovery tidak hanya berhenti sampai pen-subsideran pidana uang pengganti, tetapi juga terjadi ketidakseimbangan antara pidana uang pengganti yang harus dibayar dengan pidana subsider yang dijalani. Penyebab munculnya ketidaksebandingan uang pengganti dengan pidana subsider karena tidak adanya acuan yang menjadi panduan hakim dalam memutuskan besar kecilnya pidana subsider yang dijatuhkan, maka subjektivitas hakim merupakan satu-satunya ukuran. Realitas ini menimbulkan kekhawatiran terjadinya abuse of power akibat adanya discretionary power yang sedemikian besar akibat jaminan yang diberikan undangundang atas kebebasan hakim dalam menangani perkara pidana menjadi demikian terbuka (Zulfa, 2011: 40).

Beberapa contoh putusan Pengadilan Tindak Pidana Korupsi yang menunjukkan ketidaksebandingan antara pidana uang pengganti dengan pidana subsider yang dijalani, seperti terlihat pada bagan di bawah ini:

Tabel 1. Ketidaksebandingan Uang Pengganti dengan Pidana Subsidernya

\begin{tabular}{ccll}
\hline No. & \multicolumn{1}{c}{ Putusan } & Uang Pengganti & Pidana Penjara Pengganti \\
\hline 1. & Nomor $746 \mathrm{~K} / \mathrm{Pid} . S u s / 2010$ & Rp115.381.189,- & 6 bulan \\
\hline 2. & Nomor $17 \mathrm{~K} /$ Pid.Sus/2010 & Rp148.145.833,- & 2 bulan \\
\hline 3. & Nomor 2790 K/Pid.Sus/2011 & Rp150.000.000,- & 3 bulan \\
\hline 4. & Nomor $1087 \mathrm{~K} /$ Pid.Sus/2012 & Rp150.000.000,- & 5 bulan \\
\hline 5. & Nomor 2360 K/Pid.Sus/2013 & Rp155.000.000,- & 15 bulan \\
\hline 6. & Nomor 11 K/Pid.Sus/2014 & Rp599.550.000,- & 8 bulan \\
\hline 7. & Nomor 1/K/Pid.Sus/2015 & Rp681.045.454,- & 6 bulan
\end{tabular}

Sumber: Sistem Informasi Mahkamah Agung Tahun 2015 
Disparitas ini memperlihatkan bahwa penjatuhan uang pengganti dalam jumlah besar tidak serta merta diikuti dengan pidana penjara pengganti dalam kurun waktu yang sepadan dengan nilai uang pengganti. Begitu pula sebaliknya, jika uang pengganti yang dijatuhkan cukup besar namun pidana penjara pengganti yang ditetapkan tidak seimbang, bahkan lebih rendah dari uang pengganti yang jumlahnya lebih kecil dalam putusan yang lain. Contohnya (lihat tabel 1) pada Putusan Nomor $746 \mathrm{~K} / \mathrm{Pid}$. Sus/2010, nilai uang penggantinya sebesar Rp115.381.189,- pidana subsidernya enam bulan, sedangkan Putusan Nomor 17 K/Pid.Sus/2010 nilai uang penggantinya Rp148.145.833,- tetapi pidana subsidernya jauh lebih ringan yaitu dua bulan, padahal jumlah uang penggantinya lebih besar dari Putusan Nomor 746 K/Pid.Sus/2010. Begitu pula pada Putusan Nomor 2360 K/Pid. Sus/2013, nilai uang pengganti Rp155.000.000,pidana subsidernya 15 bulan, sedangkan Putusan Nomor $11 \mathrm{~K} / \mathrm{Pid}$.Sus/2014 nilai uang pengganti Rp599.000.000,- pidana subsidernya lebih ringan hanya delapan bulan.

Pidana subsider selama ini tidak mengandung ukuran yang konsisten antara satu perkara dengan perkara lain, sehingga disparitas yang lebar berpotensi menimbulkan pilihan bagi terpidana untuk memilih tambahan pidana penjara ketimbang mengembalikan uang negara yang dikorupsi (Munzil et al, 2015: 29-30). Putusan di atas menunjukkan terjadi ketidaksebandingan antara pidana uang pengganti dengan pidana subsider yang dijalani terpidana.

Putusan ini juga menggambarkan problematika proses asset recovery yang dilakukan penegak hukum belum menunjukkan hasil yang maksimal, karena adanya kecenderungan umum para hakim mengikuti pola berpikir legal positivism, dan jarang sekali ditemukan hakim yang mengikuti cara berfikir non-positivistik dalam memutuskan perkara (Syamsudin, 2011: 173). Itu sebabnya angka tindak pidana korupsi tetap tinggi dengan nilai kerugian negara cukup besar karena putusan pengadilan tidak memberikan efek jera untuk bagi terpidana korupsi.

\section{KESIMPULAN}

1. Putusan Nomor 62/Pid.Sus/Tipikor/2013/ PN.PBR belum mampu mengembalikan kerugian negara/daerah sebagai korban karena tidak memberikan pemulihan (restorasi) terhadap kerugian materiil yang diderita Dinas Kependudukan dan Catatan Sipil Kabupaten Indragiri Hulu. Dalam pertimbangannya hakim mengabaikan laporan hasil investigasi Badan Pengawasan Keuangan dan Pembangunan yang menunjukkan adanya kerugian keuangan daerah secara riil dan pasti jumlahnya sebesar Rp 960.386.000,- padahal secara kausalitas kerugian tersebut muncul karena adanya perbuatan melawan hukum berupa penyalahgunaan wewenang yang dilakukan terdakwa $\mathrm{M}$ dan sebagai fakta persidangan yang seharusnya menjadi dasar penjatuhan pidana uang pengganti, tetapi majelis hakim hanya menjatuhkan pidana penjara dan denda. Hakim dalam pertimbangannya tidak melihat hak ekonomi korban secara luas yang berkaitan langsung dengan kepentingan pelayanan masyarakat di Kec. Rengat, Kec. Pasir Penyu, Kec. Peranap, Kec. Batang Peranap, Kec. Batang Gangsal, Kec. Lirik, Kec. Lubuk Batu Jaya, dan Kec. SeiLala. 
2. Problematika pemulihan aset (asset recovery) dalam putusan pengadilan tindak pidana korupsi dihadapkan pada realitas ketidakmampuan terpidana untuk membayar pidana uang pengganti yang secara normatif dimungkinkan dalam Pasal 18 ayat (3) Undang-Undang Nomor 31 Tahun 1999 tentang Pemberantasan Tindak Pidana Korupsi. Kenyataannya masih ada aset tersembunyi milik terpidana yang belum dilakukan penyitaan oleh penegak hukum. Realitas ini tidak sejalan dengan teori pengembalian aset (asset recovery) yang setia pada prinsip "berikan kepada negara apa yang menjadi haknya." Akibatnya keadilan ekonomi tidak bisa dicapai karena terpidana memilih menjalani pidana subsider dan negara tetap merugi. Selain itu, terjadi ketidaksebandingan antara pidana uang pengganti yang harus dibayar dengan pidana subsider yang dijalani.

\section{SARAN}

1. Hakim sebagai insan kekuasaan yudikatif menjadi ujung tombak dalam memeriksa, mengadili, dan memutus perkara tindak pidana korupsi. Demi mengembalikan kerugian negara disarankan kepada hakim sebelum memutus agar menggunakan pendekatan keseimbangan yang mendalam, bukan hanya menjatuhkan pidana penjara dan denda, tetapi juga memperhatikan kepentinganekonominegara sebagaikorban karena berkaitan dengan kepentingan hajat hidup masyarakat luas.

2. Upaya memulihkan kerugian keuangan negara (asset recovery) hakim dihadapkan pada problematika yuridis Pasal 18 ayat (3) Undang-Undang Pemberantasan Tindak Pidana Korupsi yang membolehkan hakim untuk mensubsiderkan pidana uang pengganti dengan pidana penjara, dan realitasnya terpidana lebih memilih pidana subsider dibandingkan harus mengembalikan kerugian keuangan negara. Mengatasi problem tersebut disarankan hakim agar berhukum progresif dengan melakukan penemuan hukum (rechtsvinding) atau terobosan hukum (rule breaking) untuk mengatasi kekakuan hukum positif yang didasarkan pada kejujuran, kemanfaatan, dan keadilan bagi pencari keadilan (justitiabelen).

\section{DAFTAR ACUAN}

Alfitra. (2012). Hukum pembuktian dalam beracara pidana, perdata \& korupsi di Indonesia. Jakarta: Raih Asa Sukses.

Alkostar, A. (2008, Oktober). Kerugian keuangan negara dalam perspektif tindak pidana korupsi. Majalah Hukum Varia Peradilan, XXIII(275), 33-41.

Anshar. (2018, Agustus). Infra petita putusan pengadilan tindak pidana korupsi yang menerobos ketentuan pemidanaan minimum. Jurnal Yudisial, 11(2), 151-170.

Arief, B.N. (2009, Desember). Pembaruan penegakan hukum dengan nilai-nilai moral religius. Makalah disampaikan pada Seminar Nasional Menembus Kebuntuan Legal Formal Menuju Pembangunan Hukum dengan Pendekatan Hukum Progresif. Semarang: FH Undip.

Berdiansyah. (2017, Desember). Analisis yuridis 
terhadap pengadaan barang \& jasa guna mencegah korupsi. Jurnal Integritas, 3(2), 79104.

Fuady, M. (2004). Anatomi kejahatan kerah putih. Bandung: Citra Aditya Bakti.

(2010). Dinamika teori hukum. Bogor: Ghalia Indonesia.

Hafidz, J. (2015). Korupsi dalam perspektf HAM. Jakarta: Sinar Grafika.

Latief, A. (2014). Hukum administrasi dalam tindak pidana korupsi. Jakarta: Prenada Media Group.

Mahmud, A. (2017 Desember). Dinamika pembayaran uang pengganti dalam tindak pidana korupsi. Jurnal Mimbar Justitia, 3(2), 137-156.

Manan, B. (2006, Agustus). Hakim \& Pemidanaan. Majalah Hukum Varia Peradilan, 249, 7-12.

Mas, M. (2015). Pemberantasan tindak pidana korupsi. Bogor: Ghalia Indonesia.

Minarno, B. (2009). Penyalahgunaan wewenang \& tindak pidana korupsi dalam pengelolaan keuangan daerah. Jakarta: Laksbang Mediatama.

Munzil, F., et al. (2015, Januari). Kesebandingan pidana uang pengganti \& pengganti pidana uang pengganti dalam rangka melindungi hak ekonomi negara. Jurnal Ius Quia Iustum, 22(1), 25-53.

Nugroho, E. (2014, September). Pemanfaatan teknologi informasi dalam rangka memberantas tindak pidana korupsi secara elektronik. Jurnal Dinamika Hukum, 14(3), 539-546.

Pardede, R. (2015, Februari). Pengembalian kerugian keuangan negara ditinjau dari tujuan pembentukan Undang-Undang Nomor 31 Tahun 1999 Tentang Tindak Pidana Korupsi. Disertasi Pascasarjana Unisba. Bandung:
Tidak Dipublikasi.

Prasetyo, T. (2010). Kriminalisasi dalam hukum pidana. Bandung: Nusa Media.

Rahman, A. (2016, Mei). Penguatan lembaga Komisi Yudisial sebagai upaya mencegah \& menanggulangi judicial corruption lembaga peradilan. Jurnal Simbur Cahaya, XXIII(2), 4518-4539.

Ravena, D., \& Kristian. (2017) Kebijakan kriminal. Jakarta: Prenada Media Group.

Rifa'i, A. (2014). Penemuan hukum oleh hakim dalam perspektif hukum progresif. Jakarta: Sinar Grafika.

Santoso, T. (2013, September). Menguak relevansi ketentuan gratifikasi di Indonesia. Jurnal Dinamika Hukum, 13(3), 402-414.

Setiadi, E. (2010). Hukum pidana ekonomi. Yogyakarta: Graha Ilmu.

Shoim, M. (2009). Laporan penelitian individual (Pengaruh pelayanan publik terhadap tingkat korupsi pada lembaga peradilan di Kota Semarang). Semarang: Pusat Penelitian IAIN Walisongo.

Sinta, A. (2017, Mei). Pertanggungjawaban pidana \& pemidanaan terhadap pelaku pedofilia dalam hukum pidana Indonesia. Jurnal Magister Hukum Udayana, 6(1), 23-36.

Sutatiek, S. (2013). Menyoal akuntabilitas moral hakim pidana. Yogyakarta: Aswaja Pressindo.

Syamsudin, M. (2011, Januari). Rekonstruksi pola pikir hakim dalam memutuskan perkara korupsi berbasis hukum progresif. Jurnal Dinamika Hukum, 11(1), 11-21.

. (2012, April). Keadilan subtantif yang terabaikan dalam sengketa sita jaminan. Jurnal Yudisial, 5(1), 36-50. 
Triningsih, A. (2015, Maret). Pengadilan sebagai lembaga penegakan hukum. Jurnal Konstitusi, 12(1), 134-153.

Yanuar, P. (2015). Pengembalian aset hasil korupsi. Bandung: PT Alumni.

Zulfa, A. (2011). Paradigma pergeseran pemidanaan. Bandung: CV Lubuk Agung. 